\title{
The Effect of Initial Oxidation on Long-Term Oxidation of NiCoCrAlY Alloy
}

\author{
Chao Zhu, Xiaoyu Wu, Yuan Wu, Gongying Liang \\ MOE Key Laboratory for Nonequilibrium Synthesis and Modulation of Condensed Matter, \\ School of Science, Xi'an Jiaotong University, Xi'an, China \\ E-mail: gyliang@mail.xjtu.edu.cn \\ Received March 8, 2010; revised June 3, 2010; accepted June 5, 2010
}

\begin{abstract}
The initial oxidation behavior of Ni-6.5Co-17.8Cr-3.7Al- $0.5 \mathrm{Y}$ alloy is investigated at $800^{\circ} \mathrm{C}-1000^{\circ} \mathrm{C}$. X-ray diffraction results show that the dominant $\mathrm{Cr}_{2} \mathrm{O}_{3}$ phase and secondary $\alpha-\mathrm{Al}_{2} \mathrm{O}_{3}$ and $\mathrm{NiO}$ phases are observed on the surface of samples at all initial stages (oxidized for 16 hours). $\mathrm{YAlO}_{3}$ and $\theta-\mathrm{Al}_{2} \mathrm{O}_{3}$ can only be detected at low temperature $\left(800^{\circ} \mathrm{C}\right)$ while the spinel $\mathrm{NiCr}_{2} \mathrm{O}_{4}$ is only observed at $900^{\circ} \mathrm{C}$ and $1000^{\circ} \mathrm{C}$. Though the growth rates of $\alpha-\mathrm{Al}_{2} \mathrm{O}_{3}$ and $\mathrm{Cr}_{2} \mathrm{O}_{3}$ are comparable at $900^{\circ} \mathrm{C}$, the former becomes much lower than the latter when the temperature changes to $1000^{\circ} \mathrm{C}$. Scanning electron microscopy (SEM) images show that the $\alpha-\mathrm{Al}_{2} \mathrm{O}_{3}$ grows from some irregular ditches in the chromia scale at $900^{\circ} \mathrm{C}$. However, cracking and spalling are more serious at $1000^{\circ} \mathrm{C}$ without $\alpha-\mathrm{Al}_{2} \mathrm{O}_{3}$-grown-ditches, which is in accordance with the growth rates of these oxides at different temperatures. The cracking can be explained by the results of Raman determination which indicate that the stress on the surface of specimen oxidized at $1000^{\circ} \mathrm{C}$ is higher than that at $900^{\circ} \mathrm{C}$. Owing to this condition, a preoxidation treatment on the NiCoCrAlY alloy for 16 hours is prepared at $900^{\circ} \mathrm{C}$, and then thermal cycling oxidation test is conducted at $1000^{\circ} \mathrm{C}$ for 200 hours. The result indicates that the initial preoxidation treatment at $900^{\circ} \mathrm{C}$ improves the oxidation resistance of alloy at $1000^{\circ} \mathrm{C}$.
\end{abstract}

Keywords: NiCoCrAlY, Oxidation Kinetics, Initial Oxidation, $\mathrm{Al}_{2} \mathrm{O}_{3}, \mathrm{Cr}_{2} \mathrm{O}_{3}$

\section{Introduction}

$\mathrm{NiCrCoAlY}$ alloys are often used as bond coatings of thermal barrier coatings (TBCs) to protect the substrate from oxidation at high temperature and to provide the necessary adhesion of the ceramic to the substrate [1-3]. Some authors [4-7] indicated that the protection offered by MCrAlY (M=Ni, Co or a combination) alloys against high temperature oxidation relies on the ability of the alloy to develop and maintain a continuous, dense and slow growing $\alpha-\mathrm{Al}_{2} \mathrm{O}_{3}$ scale. The formation of a continuous of alumina $\left(\mathrm{Al}_{2} \mathrm{O}_{3}\right)$ layer during the oxidation of the substrate at high temperatures could result in a dramatic slowing down of the oxidation process, because $\mathrm{Al}_{2} \mathrm{O}_{3}$ formation has a slower rate of oxidation compared to other oxidations. Generally, the protectiveness of the alloy surface at long-term stage is frequently determined by the initial stage of oxidation [8-10].

The project was supported by the State Key Development Program for Basic Research of China (Grant No. 2007CB707700).
Besides alumina, chromia $\left(\mathrm{Cr}_{2} \mathrm{O}_{3}\right)$ also plays an important role during the high temperature oxidation [11-13]. However, the effect of the interaction among the oxides on the oxidation resistance of alloy has not been discussed in detail. In particular, there has been a lack of attention to the initial stages of oxidation on NiCoCrAlY alloy to date.

Raman spectroscopy has been used as a non-destructive technique for determining the stresses in oxide scales for decades due to the bands in the Raman spectra of specimens shift with pressure [11-13]. The salient features of the Raman technique are that it does not require a special environment, and it provides a high resolution.

The aim of this study is to improve the service life of the alloys. The evolution of the oxide scale on the surface of NiCoCrAlY alloy at initial stage oxidized at $800^{\circ} \mathrm{C}-1000^{\circ} \mathrm{C}$ were investigated. After reporting the experimental results, a method to improve the oxidation resistance was proposed by utilizing the interaction cha- 
racteristics of $\mathrm{Al}_{2} \mathrm{O}_{3}$ and $\mathrm{Cr}_{2} \mathrm{O}_{3}$ growth.

\section{Experimental}

The original powder was commercially available, and its component was $6.5 \% \mathrm{Co}, 17.8 \% \mathrm{Cr}, 3.7 \% \mathrm{Al}, 0.5 \% \mathrm{Y}$, balance $\mathrm{Ni}$ (wt.\%) with an average particle size of 16.34 $\mu \mathrm{m}$.

The powder was heated and compacted into the form of a cylindrical rod of green density equal to $89 \pm 5 \%$ of its theoretical density at inner temperature of $800^{\circ} \mathrm{C}$ for 2 hours with a pressure of $300 \mathrm{MPa}$. Subsequently, the rod was annealed in vacuum at $1000^{\circ} \mathrm{C}$ for 1 hour in order to homogenize and recrystallize the alloy.

Disc shaped specimens (diameter $15 \mathrm{~mm}$ and thickness $1 \mathrm{~mm}$ ) were cut from the rod using spark-machining. The specimen surface was ground and polished. After each preparation step the specimens were thoroughly cleaned ultrasonically with alcohol.

Isothermal oxidation was performed in static air at 1 atm pressure in a resistance furnace which has a maximum operating temperature of $1300^{\circ} \mathrm{C}$. All the specimens were put into the furnace at the same time after the test temperature was reached. Then, oxidized specimens were removed out from the furnace after a chosen time and air-cooled to room temperature. The initial oxidation tests were performed at $800^{\circ} \mathrm{C}, 900^{\circ} \mathrm{C}$ and $1000^{\circ} \mathrm{C}$ for 2 , 4,8 and 16 hours.

A thermal cycling oxidation test was conducted at $1000^{\circ} \mathrm{C}$ for 200 hours. In order to keep consistent of oxidation condition in the test, the specimens were preoxidized at $900^{\circ} \mathrm{C}$ and $1000^{\circ} \mathrm{C}$ for 16 hours. Then the oxidation behavior of the specimens was evaluated by measuring the weight gains of the samples for 184 hours. The 12-hour cycle consisted of 11 hours holding at $1000^{\circ} \mathrm{C}$, followed by cooling in air for 1 hour. The precision of the balance was $0.1 \mathrm{mg}$.

Raman spectroscopy was used here in order to determine the stresses in chromia scales formed at $900^{\circ} \mathrm{C}$ and $1000^{\circ} \mathrm{C}$ on NiCoCrAlY alloy. Chromia has the same structure as corundum, and therefore it should have seven Raman active bands $\left(\mathrm{A}_{1 \mathrm{~g}}+5 \mathrm{E}_{\mathrm{g}}\right)$ [11-13]. The most intense mode is the $549 \mathrm{~cm}^{-1} \mathrm{~A}_{1 \mathrm{~g}}$ vibration [11] and this one was used for monitoring the stress.

The spectroscopy was measured at room temperature using the Renishaw Ramanscope 1000 (Renishaw $^{\mathrm{TM}}$, Gloucestershire, UK) in conjunction with an Olympus BH-2 microscope. During the measurements, the laser $(\mathrm{He}-\mathrm{Ne}, 632.8 \mathrm{~nm})$ was focused at a position on the surface of the sample and the laser spot size was set about 3-5 $\mu \mathrm{m}$. The Raman spectroscopy acquired was analyzed by the commercial Renishaw WiRe software to obtain the peak shift fitted by Gaussian-Lorentzian function.

The surface morphologies and polished cross sections of the specimens were observed using a scanning elec- tron microscopy (SEM) (JSM-7000F). The chemical composition of the oxides was determined qualitatively by energy-dispersive X-ray analysis (EDX). The phases in the oxide scales were analyzed using an X-ray diffraction (XRD) (Rigaku D, CuK $\alpha$ radiation).

\section{Results and Discussion}

\subsection{The Oxides on the Surface after Initial Oxidation}

X-ray diffraction patterns of NiCoCrAlY alloy after oxidation for 16 hours at $800^{\circ} \mathrm{C}, 900^{\circ} \mathrm{C}$ and $1000^{\circ} \mathrm{C}$ are shown in Figure 1. Results from the study show that the oxides on the surface of alloy which was heated to $800^{\circ} \mathrm{C}$ for 16 hours are composed of $\mathrm{Cr}_{2} \mathrm{O}_{3}$, a few $\theta-\mathrm{Al}_{2} \mathrm{O}_{3}$ and $\mathrm{YAlO}_{3}$, trace $\alpha-\mathrm{Al}_{2} \mathrm{O}_{3}$ and $\mathrm{NiO}$. It was found that however, oxides $\theta-\mathrm{Al}_{2} \mathrm{O}_{3}$ and $\mathrm{YAlO}_{3}$ did not form at $900^{\circ} \mathrm{C}$ and $1000^{\circ} \mathrm{C}$. The spinel oxide, $\mathrm{NiCr}_{2} \mathrm{O}_{4}$, began to exist after 16 hours of oxidation at $900^{\circ} \mathrm{C}$.

According to the intensity of diffraction peaks, the relative oxidation rates of $\mathrm{Cr}_{2} \mathrm{O}_{3}$ and $\alpha-\mathrm{Al}_{2} \mathrm{O}_{3}$ phases on the surface of alloy oxidized from 2 hours to 16 hours at $800^{\circ} \mathrm{C}, 900^{\circ} \mathrm{C}$ and $1000^{\circ} \mathrm{C}$ are shown in Figure 2.

From Figure 2(a), Figure 2(b), it can be seen that the relative quantities of $\mathrm{Al}_{2} \mathrm{O}_{3}$ and $\mathrm{Cr}_{2} \mathrm{O}_{3}$ increased quickly in the first two hours. After that, the oxidation rate of $\mathrm{Al}_{2} \mathrm{O}_{3}$ rises slowly while the relative quantities of $\mathrm{Cr}_{2} \mathrm{O}_{3}$ at $900^{\circ} \mathrm{C}$ and $1000^{\circ} \mathrm{C}$ keep fluctuating. The increase of quantities of $\alpha-\mathrm{Al}_{2} \mathrm{O}_{3}$ resulted from dense $\alpha-\mathrm{Al}_{2} \mathrm{O}_{3}$ oxide forming and $\theta-\mathrm{Al}_{2} \mathrm{O}_{3}$ transforming. The fluctuation of quantities of $\mathrm{Cr}_{2} \mathrm{O}_{3}$ at $900^{\circ} \mathrm{C}$ and $1000^{\circ} \mathrm{C}$ may have been caused by spinel oxides $\mathrm{NiCr}_{2} \mathrm{O}_{4}$ formation which consumed $\mathrm{Cr}_{2} \mathrm{O}_{3}$. With the increased temperature or prolonged exposure time, $\mathrm{NiO}$ eventually became destabilized and reacted with $\mathrm{Cr}_{2} \mathrm{O}_{3}$ to form a thin spinel layer of $\mathrm{NiCr}_{2} \mathrm{O}_{4}$, which was thermodynamically more stable [9,14-16]. The competition between the consumption of

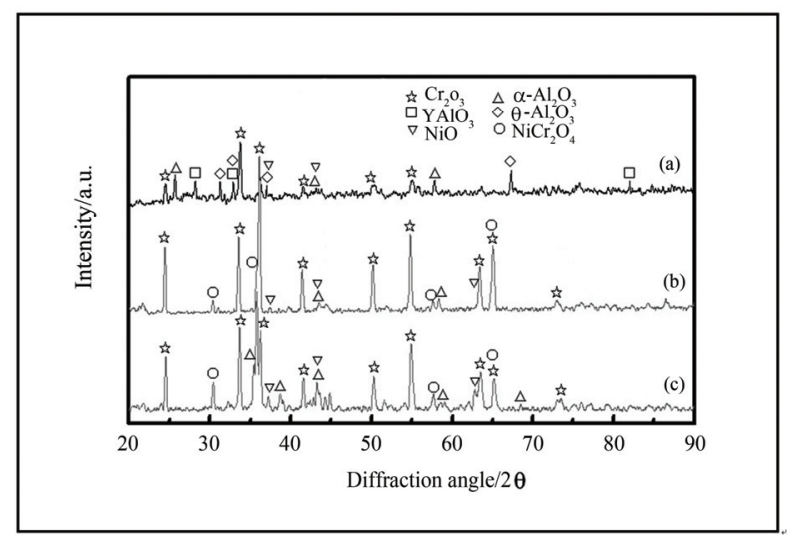

Figure 1. X-ray diffraction patterns of Ni6.5Co17.8Cr3.7 Al0.5Y alloy (oxidized for $16 \mathrm{~h}$ ) at (a) $800^{\circ} \mathrm{C}$; (b) $900^{\circ} \mathrm{C}$ and (c) $1000^{\circ} \mathrm{C}$. 


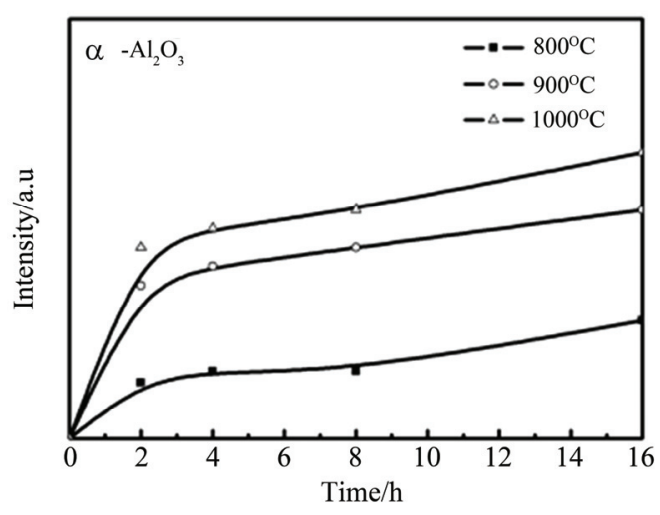

(a)

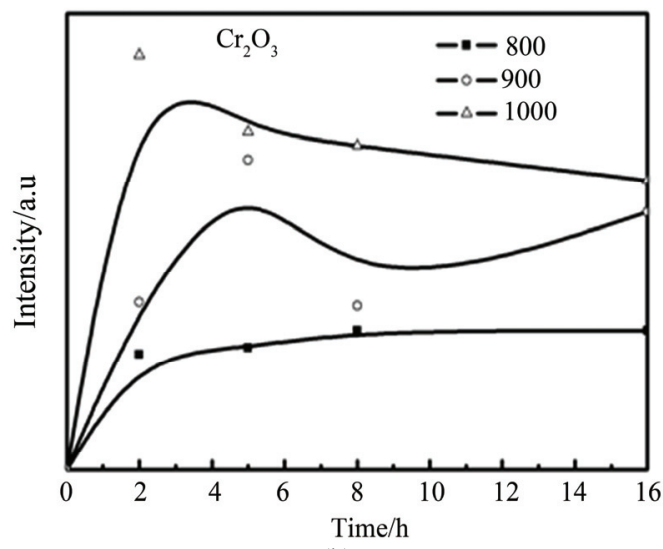

(b)

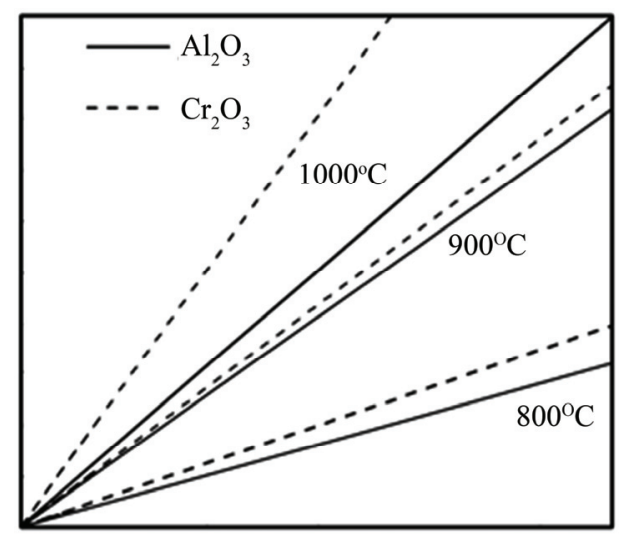

(c)

Figure 2. Relative quantities of $\mathrm{Cr}_{2} \mathrm{O}_{3}$ and $\alpha-\mathrm{Al}_{2} \mathrm{O}_{3}$ phases on the surface of alloy vs. time: (a) $\alpha-\mathrm{Al}_{2} \mathrm{O}_{3}$; (b) $\mathrm{Cr}_{2} \mathrm{O}_{3}$; (c) the relative oxidation rates of $\mathrm{Cr}_{2} \mathrm{O}_{3}$ and $\alpha-\mathrm{Al}_{2} \mathrm{O}_{3}$ at the second hour at $800^{\circ} \mathrm{C}, 900^{\circ} \mathrm{C}$ and $1000^{\circ} \mathrm{C}$.

$\mathrm{Cr}_{2} \mathrm{O}_{3}$ and the formation of $\mathrm{Cr}_{2} \mathrm{O}_{3}$ determined the outline of curve.

Figure 2(c) shows that the relative oxidation rates of $\alpha-\mathrm{Al}_{2} \mathrm{O}_{3}$ and $\mathrm{Cr}_{2} \mathrm{O}_{3}$ increased with temperature in the second hour from $800^{\circ} \mathrm{C}$ to $1000^{\circ} \mathrm{C}$. Also, it can be observed that the growth rate of $\alpha-\mathrm{Al}_{2} \mathrm{O}_{3}$ is similar to that of $\mathrm{Cr}_{2} \mathrm{O}_{3}$ at $900^{\circ} \mathrm{C}$. However, at $1000^{\circ} \mathrm{C}$, the increase of growth rate of $\alpha-\mathrm{Al}_{2} \mathrm{O}_{3}$ is not as much as the growth rate of $\mathrm{Cr}_{2} \mathrm{O}_{3}$.

\subsection{The Cracking and Closure of the Oxide Scale in Initial Oxidation}

A SEM image of the specimen surface oxidized in air for up to 16 hours at $800^{\circ} \mathrm{C}$ is shown in Figure 3(a). Figure 3(b) is at a higher magnification. These images show that some protrudes, pores and pits are presented on the surface, but few cracks appeared.

The whisker or needlelike oxide phase is observed. The EDX analysis (Figure 3(c), Figure 3(d)) of the oxide whiskers produced $\mathrm{Al}, \mathrm{Cr}$ and $\mathrm{O}$ peaks, which is qualitatively identified as $\mathrm{Al}_{2} \mathrm{O}_{3}$ and $\mathrm{Cr}_{2} \mathrm{O}_{3}$ phases. As the $\theta-\mathrm{Al}_{2} \mathrm{O}_{3}$ phase usually grows in a needlelike, whiskerlike or bladelike morphology and $\alpha-\mathrm{Al}_{2} \mathrm{O}_{3}$ grows in a weblike or dense equiaxed structure $[14,17]$, these bladelike oxides should be $\theta-\mathrm{Al}_{2} \mathrm{O}_{3}$.
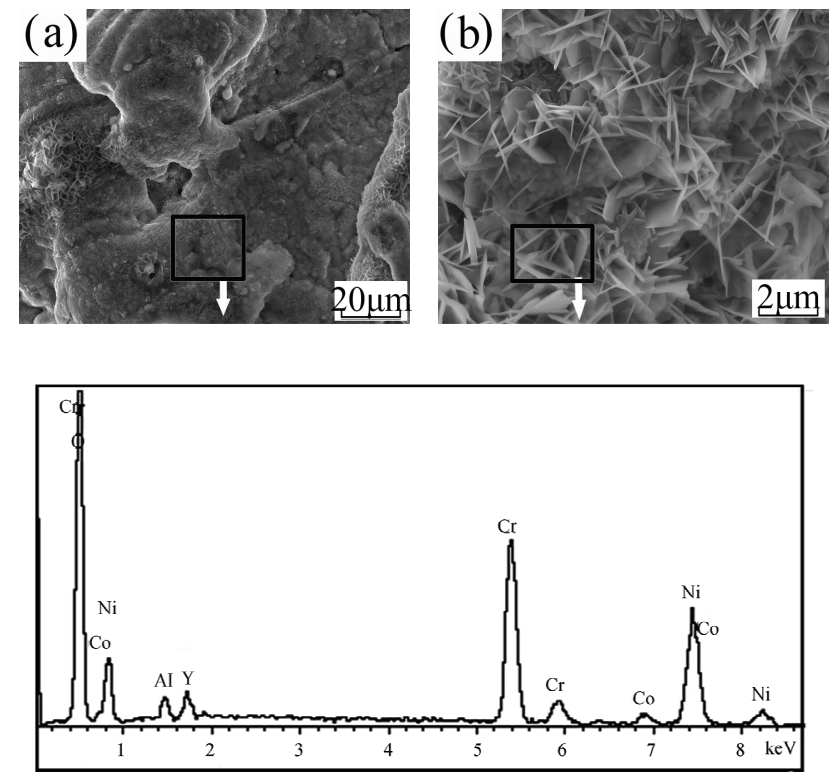

(c)

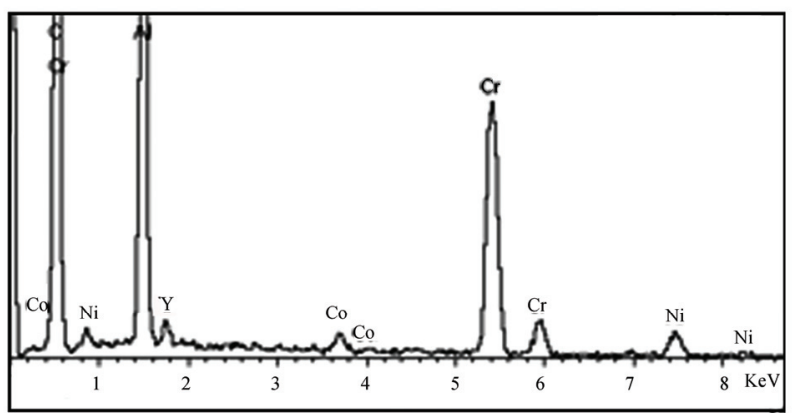

(d)

Figure 3. SEM images of the specimen surface (oxidized for $16 \mathrm{~h}$ at $800^{\circ} \mathrm{C}$ ) (a) surface image; (b) higher magnification; (c) and (d) EDX analysis in selected region. 
The surface images of specimens exposed at $900^{\circ} \mathrm{C}$ and $1000^{\circ} \mathrm{C}$ in a static atmosphere for 16 hours are shown in Figure 4(a), Figure 4(b). It was found that specimens covered with fine oxide particles. It was also observed irregular ditches on the surface at both temperatures and cracks in the oxide scale. The cracks became more serious as the temperature increased. The spallation on the surface of the oxidized specimen was unavoidable.

It may have resulted from the stress during the cooling and heating process and the mismatch between the expansion coefficients of oxides and alloys.
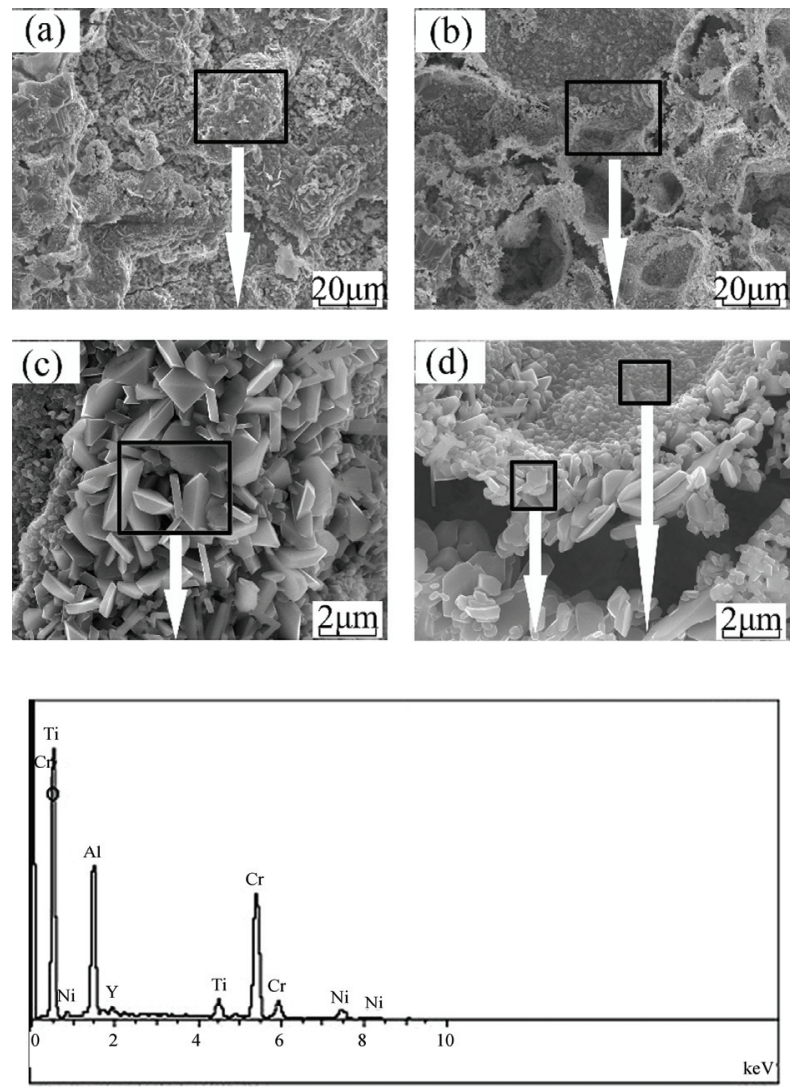

(e)

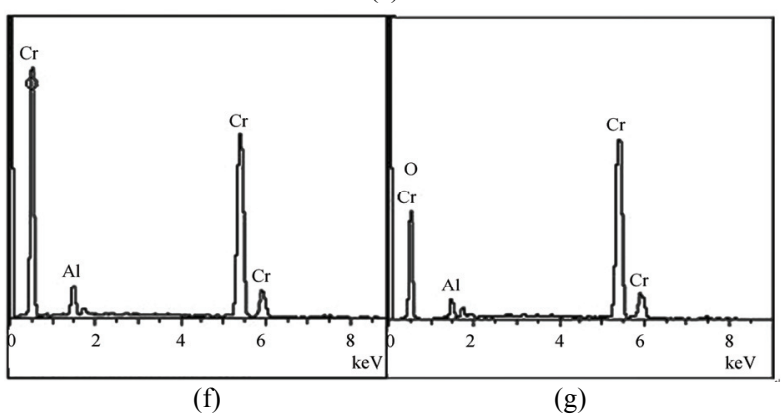

Figure 4. The surface images of specimens (oxidized for $16 \mathrm{~h}$ at $900^{\circ} \mathrm{C}$ and $1000^{\circ} \mathrm{C}$ ) (a) specimens oxidized at $900{ }^{\circ} \mathrm{C}$; (b) specimens oxidized at $1000^{\circ} \mathrm{C}$; (c) higher magnification of Figure. 4(a); (d) higher magnification of Figure. 4(b); (e), (f) and (g) EDX analysis in selected regions.
EDX analysis (Figure 4(f), $\mathbf{4 ( g ) )}$ shows that the oxides around the cracks are $\mathrm{Cr}_{2} \mathrm{O}_{3}$ (Figure $4(\mathbf{d})$ ). This indicates that these cracks were caused by the $\mathrm{Cr}_{2} \mathrm{O}_{3}$ oxide scale broke during the oxidation. At the same time, it was observed that some oxides were growing from the cracks in Figure 4(c). By EDX analysis, it is confirmed that these oxides are $\alpha-\mathrm{Al}_{2} \mathrm{O}_{3}$ and $\mathrm{Cr}_{2} \mathrm{O}_{3}$. It can be speculated that, at $900^{\circ} \mathrm{C}, \alpha-\mathrm{Al}_{2} \mathrm{O}_{3}$ grew form the bottom of the $\mathrm{Cr}_{2} \mathrm{O}_{3}$ oxide scale cracks, which filled in the cracks and made the oxide scale dense. Contrasting Figure 4(a) with Figure 4(b), it is can be seen that the cracks in the oxide scale at $1000^{\circ} \mathrm{C}$ are more than those at $900^{\circ} \mathrm{C}$. There are more irregular ditches observed among the $\mathrm{Cr}_{2} \mathrm{O}_{3}$ oxide scale but not so much $\alpha-\mathrm{Al}_{2} \mathrm{O}_{3}$ fill in the cracks.

Form Figure 2, we observe that the growth rate of $\alpha-\mathrm{Al}_{2} \mathrm{O}_{3}$ is similar to that of $\mathrm{Cr}_{2} \mathrm{O}_{3}$ at $900^{\circ} \mathrm{C}$. Though the spallation on the $\mathrm{Cr}_{2} \mathrm{O}_{3}$ scale was unavoidable, $\alpha-\mathrm{Al}_{2} \mathrm{O}_{3}$ could preferably nucleate during oxidation on the surface in some cracks of the oxide scale at $900^{\circ} \mathrm{C}$ where they could grow and fill in those ditches. With the density of the oxide scale increased, both the oxygen and cation diffusion rate decreased. Thus the ability of oxidation resistance would be improved. However, the growth rate of $\mathrm{Cr}_{2} \mathrm{O}_{3}$ is much larger than that of $\alpha-\mathrm{Al}_{2} \mathrm{O}_{3}$ at $1000^{\circ} \mathrm{C}$. When the oxides on the surface of the alloy grew at a larger rate, the oxide scale cracked and spalled easily. Because of the cracks, oxygen diffused through the oxide scale easily to contact the oxide-alloy interface, which speeded up the oxidation of alloy greatly.

The cross-sectional microstructure and the elemental maps of the NiCoCrAlY specimens obtained by SEM and EDX after oxidation at three different temperatures for 16 hours are shown in Figure 5. The elemental concentration regions of $\mathrm{O}, \mathrm{Cr}$ and $\mathrm{Al}$ are presented in the Figures 5( $\left.\mathbf{a}_{2}\right)-5\left(c_{4}\right)$.

From Figure 5( $\left.\mathbf{a}_{2}\right)$, Figure 5( $\left.\mathbf{b}_{2}\right)$ and Figure 5( $\left.\mathbf{c}_{2}\right)$, it was found that the thickness of the oxide layer increases with the temperature rising. A continual oxide layer formed at $900^{\circ} \mathrm{C}$, and it became thicker at $1000^{\circ} \mathrm{C}$. The $\mathrm{Cr}_{2} \mathrm{O}_{3}$ phase dominated in the oxide layers (Figure $\mathbf{5}\left(\mathbf{a}_{3}\right)$, Figure 5( $\left.\mathbf{b}_{3}\right)$ and Figure $\mathbf{5}\left(\mathbf{c}_{3}\right)$ ) while the $\mathrm{Al}_{2} \mathrm{O}_{3}$ phase was not abundant in these environments (Figure $\mathbf{5}\left(\mathbf{a}_{4}\right)$,

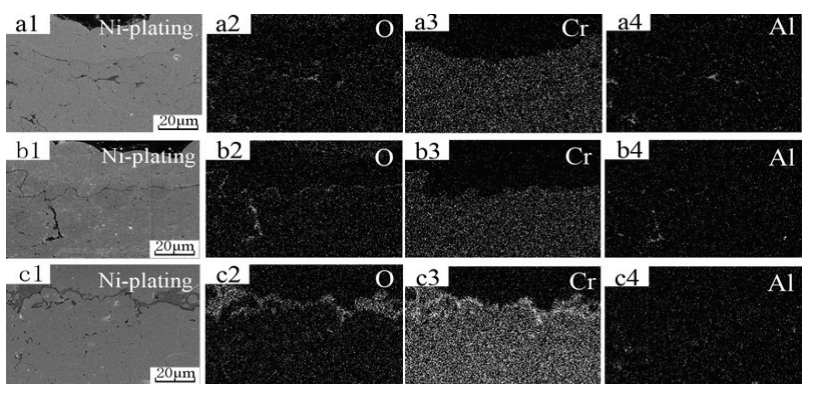

Figure 5. The cross-sectional microstructure and the elemental maps of NiCoCrAIY alloy (oxidized for $16 \mathrm{~h}$ ) at (a) $800^{\circ} \mathrm{C}$; (b) $900^{\circ} \mathrm{C}$ and (c) $1000^{\circ} \mathrm{C}$. 
Figure 5( $\left.\mathbf{b}_{4}\right)$ and Figure 5( $\left.\mathbf{c}_{4}\right)$ ). This indicated that $\mathrm{Cr}_{2} \mathrm{O}_{3}$ formed at the initial oxidation stage. Some brightness Al-containing regions denote the $\mathrm{Al}_{2} \mathrm{O}_{3}$ which filled in the $\mathrm{Cr}_{2} \mathrm{O}_{3}$ ditches (Figure $\mathbf{5}\left(\mathbf{b}_{4}\right)$ ). This is in good agreement with the XRD and surface microstructure results.

Though a continuous layer of $\mathrm{Al}_{2} \mathrm{O}_{3}$ was not appeared at the onset of the oxidation, an inner zone of isolated Al-containing phase could be observed at all three temperatures in Figure 5( $\left.\mathbf{a}_{4}\right)$, Figure 5( $\left.\mathbf{b}_{4}\right)$ and Figure 5( $\left.\mathbf{c}_{4}\right)$. This was in good agreement with the literature [10] and the Al-containing phase should be $\alpha-\mathrm{Al}_{2} \mathrm{O}_{3}$. The lateral growth of $\alpha-\mathrm{Al}_{2} \mathrm{O}_{3}$ precipitates occurred until they coalesce into a continuous $\alpha-\mathrm{Al}_{2} \mathrm{O}_{3}$ layer.

\subsection{Stress Determination}

Figure 6 shows the Raman spectrum obtained from the oxide scale formed on the surface of NiCoCrAlY alloys oxidized at $900^{\circ} \mathrm{C}$ and $1000^{\circ} \mathrm{C}$ for $16 \mathrm{~h}$. The only band which is well-defined in both spectra is the $\mathrm{A}_{1 \mathrm{~g}}$ mode at $549 \mathrm{~cm}^{-1}$ in Mougin et al.'s work [11]. In the scales, this mode shifts to $549.53 \mathrm{~cm}^{-1}$ for $900^{\circ} \mathrm{C}$ specimen and $554.34 \mathrm{~cm}^{-1}$ for $1000^{\circ} \mathrm{C}$ specimen respectively, resulting in the observed shifts are equal to $0.53 \mathrm{~cm}^{-1}$ and 5.34 $\mathrm{cm}^{-1}$ respectively. Using the law given by Mougin et al. [11] for the frequency dependence with pressure, i.e., $0.307 \pm 0.005 \mathrm{GPa} / \mathrm{cm}^{-1}$, it gives the stress values of $0.163 \pm 0.005 \mathrm{GPa}$ for $900^{\circ} \mathrm{C}$ specimen and $1.639 \pm$ $0.005 \mathrm{GPa}$ for $1000^{\circ} \mathrm{C}$ specimen respectively. The shift direction corresponds to compressive stress.

The results exhibited here agree with the previous discussion. The higher growth rate of $\mathrm{Cr}_{2} \mathrm{O}_{3}$ at $1000^{\circ} \mathrm{C}$ resulted in a higher stress than the stress generated at a lower temperature. The structure under high stress condition was easier to crack, spall and fracture and was more difficult to self-healing by the $\mathrm{Al}_{2} \mathrm{O}_{3}$ growth simultaneously.

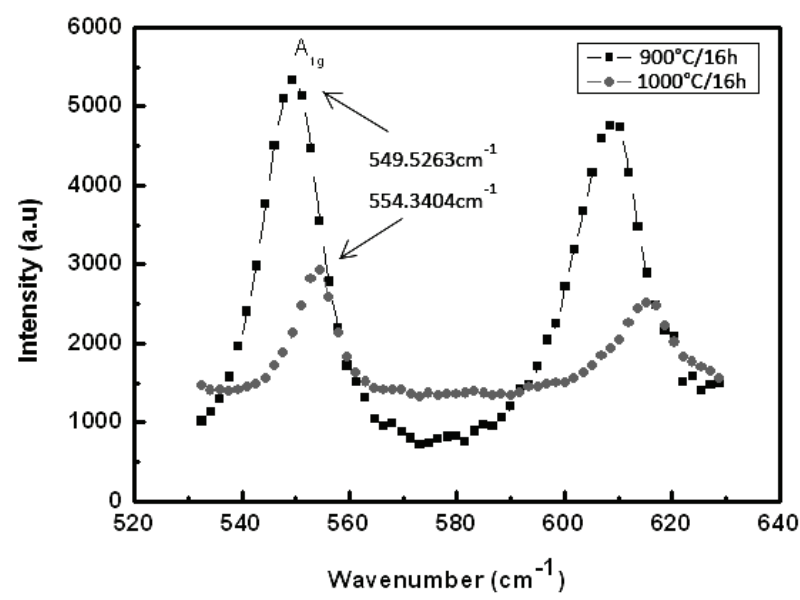

Figure 6. Raman spectrum for the chromia formed on $\mathrm{Ni}$ CoCrAIY alloys oxidized for $16 \mathrm{~h}$ at $900^{\circ} \mathrm{C}$ and $1000^{\circ} \mathrm{C}$.

\subsection{The Effect of the Preoxidation Treatment on the Oxidation Resistance}

Due to the different growth characteristics of $\alpha-\mathrm{Al}_{2} \mathrm{O}_{3}$ and $\mathrm{Cr}_{2} \mathrm{O}_{3}$ at different temperatures at initial stage of oxidation, two groups of specimen were conducted. One was directly oxidized at $1000^{\circ} \mathrm{C}$ for 200 hours. The other one was subjected to a preoxidation treatment at $900^{\circ} \mathrm{C}$ for 16 hours first, aiming to repair micro-cracks in the $\mathrm{Cr}_{2} \mathrm{O}_{3}$ scale by subsequent growth of $\alpha-\mathrm{Al}_{2} \mathrm{O}_{3}$, then oxidized at $1000^{\circ} \mathrm{C}$ for 184 hours. The oxidation behavior of the specimens was evaluated by a cyclic oxidation test.

Figure 7 represents the weight gain as a function of time for the cycle oxidation at $1000^{\circ} \mathrm{C}$. In the figure, curve (a) indicates the specimen directly oxidized at $1000^{\circ} \mathrm{C}$ for 200 hours and curve (b) indicates the specimen which preoxidixed at $900^{\circ} \mathrm{C}$. At the onset of the oxidation, the rate of weight gain of the specimen preoxidized at $900^{\circ} \mathrm{C}$ was slower than that of $1000^{\circ} \mathrm{C}$. After the sharp increase of weight gain at the initial oxidation stage, both of the kinetic curves showed an extensive period of very slow weight gain. Obviously, the alloy which preoxidised at $900^{\circ} \mathrm{C}$ showed lower weight gains than that of $1000^{\circ} \mathrm{C}$.

With oxidation depth increased, oxygen activity reduced unceasingly, $\mathrm{Al}_{2} \mathrm{O}_{3}$ precipitates would nuclear in subsurface of the alloy but no longer for $\mathrm{Cr}_{2} \mathrm{O}_{3}$. This could explain that why the relative quantity of $\alpha-\mathrm{Al}_{2} \mathrm{O}_{3}$ at $900^{\circ} \mathrm{C}$ was larger than that at $1000^{\circ} \mathrm{C}$. At $1000^{\circ} \mathrm{C}$, a great amount of $\mathrm{Cr}_{2} \mathrm{O}_{3}$ formed by the contact between $\mathrm{Cr}$ irons and the oxygen through the severe cracks.

\section{Conclusions}

Initial oxidation tests of $\mathrm{Ni}-6.5 \mathrm{Co}-17.8 \mathrm{Cr}-3.7 \mathrm{Al}-0.5 \mathrm{Y}$ alloy specimens was performed at $800^{\circ} \mathrm{C}, 900^{\circ} \mathrm{C}$ and $1000^{\circ} \mathrm{C}$ for 16 hours. $\mathrm{Cr}_{2} \mathrm{O}_{3}$ was the predominant phase at all three temperatures and the dense $\mathrm{Cr}_{2} \mathrm{O}_{3}$ scale play-

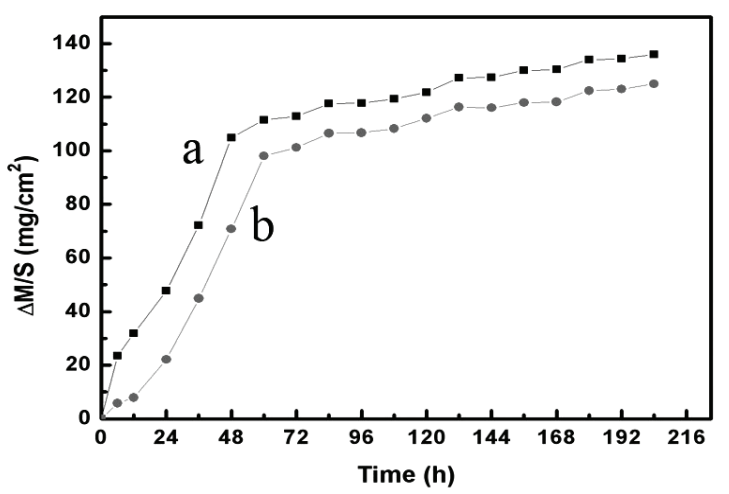

Figure 7. Weight gain of specimens vs. time in the cyclic oxidation at $1000^{\circ} \mathrm{C}$ for $200 \mathrm{~h}$ (a) directly oxidized at $1000^{\circ} \mathrm{C}$; (b) preoxidation treatment at $900^{\circ} \mathrm{C}$ for $16 \mathrm{~h}$. 
ed an important role in protecting against cracking and oxidation in the first 16 hours of the isothermal oxidation at $800^{\circ} \mathrm{C}$. $\mathrm{YAlO}_{3}$ phase was only observed at $800^{\circ} \mathrm{C}$. That the growth rate of $\alpha-\mathrm{Al}_{2} \mathrm{O}_{3}$ was similar to that of $\mathrm{Cr}_{2} \mathrm{O}_{3}$ at $900^{\circ} \mathrm{C}$ lead to the $\alpha-\mathrm{Al}_{2} \mathrm{O}_{3}$ could grow and fill in the ditches on the $\mathrm{Cr}_{2} \mathrm{O}_{3}$ scale. However, the growth rate of $\mathrm{Cr}_{2} \mathrm{O}_{3}$ at $1000^{\circ} \mathrm{C}$ was much larger and produced higher stress than that at $900^{\circ} \mathrm{C}$, so that the $\alpha-\mathrm{Al}_{2} \mathrm{O}_{3}$ grown from the $\mathrm{Cr}_{2} \mathrm{O}_{3}$ oxide ditches was not enough to fill in these cracks. Though the spallation on the surface of oxidized specimen was unavoidable at the higher temperature $\left(900^{\circ} \mathrm{C}\right.$ and $\left.1000^{\circ} \mathrm{C}\right)$, a preoxidation treatment at $900^{\circ} \mathrm{C}$ for 16 hours can cause $\alpha-\mathrm{Al}_{2} \mathrm{O}_{3}$-dispersions-in- $\mathrm{Cr}_{2} \mathrm{O}_{3}$ scale formed on the surface of the specimen. This could improve the oxidation resistance of NiCoCrAlY alloy in the thermal cycling oxidation.

\section{Acknowledgment}

The project was supported by the State Key Development Program for Basic Research of China (Grant No. 2007CB707700).

\section{References}

[1] N. P. Padture, M. Gell and E. H. Jordan, "Thermal Barrier Coatings for Gas-Turbine Engine Applications," Science, Vol. 296, No. 5566, 2002, pp. 280-284.

[2] A. G. Evans, D. R. Mumm, J. W. Hutchinson, G. H. Meier and F. S. Pettit, "Mechanisms Controlling the Durability of Thermal Barrier Coatings," Progress in Materials Science, Vol. 46, No. 5, 2001, pp. 505-553.

[3] Y. Fengling and T. D. Bennett, "Phase of Thermal Emission Spectroscopy for Properties Measurements of Delaminating Thermal Barrier Coatings," Journal of Applied Physics, Vol. 98, No. 10, 2005, pp. 103501103508.

[4] R. Panat, S. L. Zhang and K. J. Hsia, "Bond Coat Surface Rumpling in Thermal Barrier Coatings," Acta Materialia, Vol. 51, No. 1, 2003, pp. 239-249.

[5] B. Wang, J. Gong, A. Y. Wang, C. Sun, R. F. Huang and L. S. Wen, "Oxidation Behaviour of Nicraly Coatings on Ni-Based Superalloy," Surface \& Coatings Technology, Vol. 149, No. 1, 2002, pp. 70-75.

[6] U. Schulz, C. Leyens, K. Fritscher, M. Peters, B. Saruhan-Brings, O. Lavigne, J. M. Dorvaux, M. Poulain, R. Mevrel and M. L. Caliez, "Some Recent Trends in Research and Technology of Advanced Thermal Barrier
Coatings," Aerospace Science and Technology, Vol. 7, No. 1, 2003, pp. 73-80..

[7] R. A. Mahesh, R. Jayaganthan and S. Prakash, "Microstructural Characteristics and Mechanical Properties of HVOF Sprayed Nicral Coating on Superalloys," Journal of Alloys and Compounds, Vol. 468, No. 1-2, 2009, pp. 392-405.

[8] T. F. An, H. R. Guan, X. F. Sun and Z. Q. Hu "Effect of the Theta-Alpha- $\mathrm{Al}_{2} \mathrm{O}_{3}$ Transformation in Scales on the Oxidation Behavior of a Nickel-Base Superalloy with an Aluminide Diffusion Coating," Oxidation of Metals, Vol. 54, No. 3-4, 2000, pp. 301-316.

[9] S. O. Moussa and K. Morsi, "High-Temperature Oxidation of Reactively Processed Nickel Aluminide Intermetallics," Journal of Alloys and Compounds, Vol. 426, No. 1-2, 2006, pp. 136-143.

[10] T. J. Nijdam, N. M. van der Pers and W. G. Sloof, "Oxide Phase Development upon High Temperature Oxidation of Gamma-Nicral Alloys," Materials and CorrosionWerkstoffe Und Korrosion, Vol. 57, No. 3, 2006, pp. 269275.

[11] M. Kemdehoundja, J. F. Dinhut, J. L. Grosseau-Poussard and M. Jeannin, "High Temperature Oxidation of $\mathrm{Ni}_{70} \mathrm{Cr}_{30}$ Alloy: Determination of Oxidation Kinetics and Stress Evolution in Chromia Layers," Materials Science and Engineering A, Vol. 435-436, No. 5, 2006, pp. 666-671.

[12] G. Calvarin, A. M. Huntz, A. Hugot Le Goff, S. Joiret and M. C. Bernard, "Oxide Scale Stress Determination by Raman Spectroscopy Application to the $\mathrm{Nicr} / \mathrm{Cr}_{2} \mathrm{O}_{3}$ System and Influence of Yttrium," Scripta Materialia, Vol. 38, No. 11, 1998, pp. 1649-1658.

[13] P. Kofstadt, "High Temperature Corrosion," Elsevier, New York, 1988.

[14] D. Lee, M. L. Santella, I. M. Anderson and G. M. Pharr "Thermal Aging Effects on the Microstructure and ShortTerm Oxidation Behavior of a Cast $\mathrm{Ni}_{3} \mathrm{Al}$ Alloy," Intermetallics, Vol. 13, No. 2, 2005, pp. 187-196.

[15] S. Seal, S. C. Kuiry and L. A. Bracho, "Surface Chemistry of Oxide Scale on IN-738LC Superalloy: Effect of Long-Term Exposure in Air at 1173 K," Oxidation of Metals, Vol. 57, No. 3-4, 2002, pp. 297-322.

[16] S. C. Choi, H. J. Cho and D. B. Lee, "Effect of Cr, Co, and $\mathrm{Ti}$ Additions on the High-Temperature Oxidation Behavior of $\mathrm{Ni}_{3} \mathrm{Al}$," Oxidation of Metals, Vol. 46, No. 1-2, 1996, pp. 109-127.

[17] H. H. Angermann, K. Nishi, Y. Aono, M. Inagaki and H. Kodama, "Evolution of Oxides on Ni-Base ODS Superalloys," Oxidation of Metals, Vol. 48, No. 1-2, 1997, pp. 1-39. 